\title{
Weight-carrying Ability and Caching Behavior of Gray Jays, Perisoreus canadensis: Adaptations to Boreal Winters
}

\author{
LYNN L. ROGERS
}

Wildlife Research Institute, 145 West Conan Street, Ely, Minnesota 55731 USA

Rogers, Lynn L. 2005. Weight-carrying ability and caching behavior of Gray Jays, Perisoreus canadensis: Adaptations to boreal winters. Canadian Field-Naturalist 119(1): 101-104.

During 16 August to 21 September 1984, I determined how Gray Jays (Perisoreus canadensis) carried flight-loads of different weights. Three individually identifiable Gray Jays weighing 60, 68, and 80 grams, used their bills to carry flight-loads weighing up to 33 percent of bodyweight but transferred heavier flight-loads from their bills to their feet 1-2 meters after takeoff. They had difficulty carrying flight-loads over 57 percent of bodyweight, and none attempted to carry flight-loads over 66 percent of bodyweight. By using their feet to bring heavy flight-loads closer to the center of lift, Gray Jays can carry heavier loads of meat, relative to body weight, than can Common Ravens (Corvus corax) which compete with Gray Jays at carcasses in winter and which do not carry objects with their feet. During 1969-2003, year-round observations near the southern edge of the Gray Jay range in northeastern Minnesota showed that caching behavior begins in August, continues over-winter, and ends at the onset of insect activity and green-up in early May. Gray Jays' propensity to approach larger animals, including people, may not indicate unwariness but rather a superior ability and willingness to assess risks and food benefits. In the boreal forest in winter, risk of starvation is greater and risk of predation is lower than in relatively food-rich ecoregions farther south.

Key Words: Perisoreus canadensis, scavenging, food cache, flight-load, feet, competition, boreal forest, risk assessment, saliva, survival strategy, Minnesota.

Gray Jay biology has been extensively researched, and their abilities to carry meat scraps in their feet and glue food caches to branches have been reported (Brewster 1937; Bock 1961; Dow 1965; Stirling 1968; Gill 1974; Bent 1946; Strickland and Ouellet 1993). I describe how Gray Jays carry flight-loads of different weights and report additional observations on scavenging and caching behaviors in northeastern Minnesota near the southern edge of their range.

\section{Methods and Materials}

During 1969-2003, I made year-round observations of Gray Jays feeding on suet or on White-tailed Deer (Odocoileus virginianus) that were killed by vehicles or Timber/Gray Wolves (Canis lupus) near Ely, Minnesota. During 16 August to 21 September 1984, I determined weights of suet pieces carried off by three Gray Jays that were individually identifiable by their weights and by feather irregularities. I placed the suet pieces on a Hanson 500-g scale. When a Gray Jay landed and carried off one of the pieces (Figure 1), I recorded the weight of the jay, the weight of the piece it selected, and how the jay carried it.

\section{Results}

Three Gray Jays, weighing 60, 68, and $80 \mathrm{~g}$, used their bills to carry pieces of suet weighing up to 33 percent of bodyweight but transferred heavier loads (42-66 percent of bodyweight) from their bills to their feet 1-2 meters after takeoff (Table 1). They had difficulty carrying flight-loads over 57 percent of bodyweight, and none attempted to carry pieces over 66 percent of bodyweight.

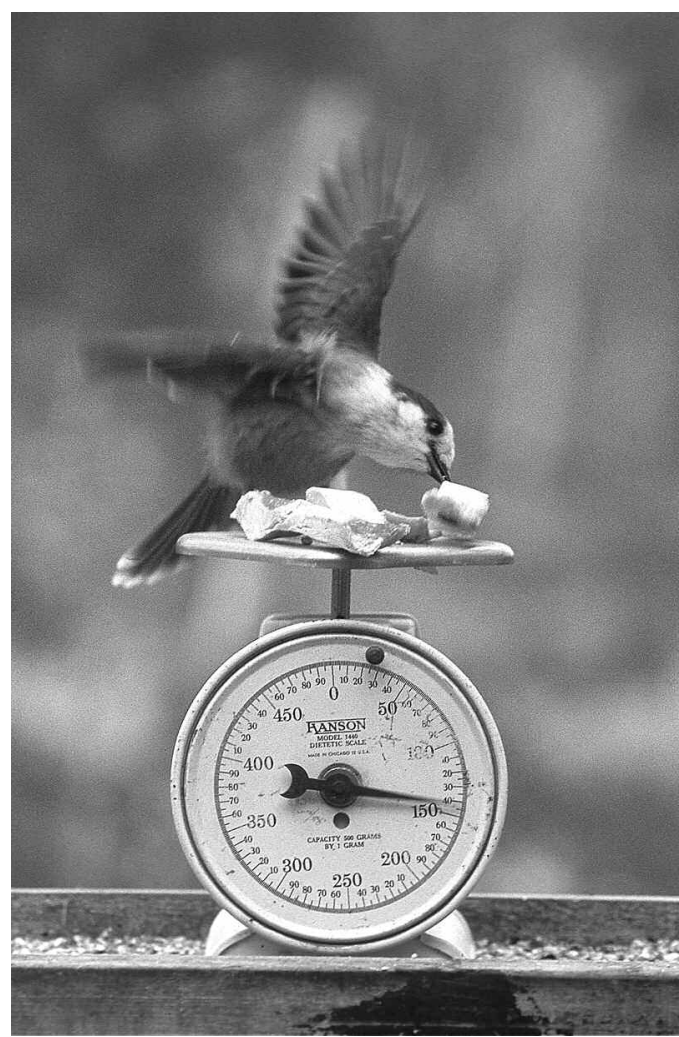

FIGURE 1. The 500-gram scale used to weigh Gray Jays and suet. Photo by Lynn Rogers. 
The Jays were successful in only 2 of 12 attempts to carry pieces of suet weighing 57-66 percent of bodyweight (Table 1). In five attempts to fly with pieces weighing 58-64 percent of bodyweight, they dropped them while attempting to transfer them from their bills to their feet (Table 1). These dropped into deep grass and were abandoned. An 80-g Jay twice dropped a 46-g piece (58 percent of bodyweight) during transfers but on the third attempt reached an altitude of 2 meters and maintained level flight for over 50 meters. A 68-g Jay carried a 43-g piece of suet (63 percent of bodyweight) plus $2 \mathrm{~g}$ of stomach contents totaling 66 percent of bodyweight. It leaped into flight from a point 1.1 meter high, lost about a meter of altitude while transferring the load from its bill to its feet, and then flew close to the ground with labored flight. In three other instances, Jays used their bills to lift pieces of suet weighing 57-60 percent of bodyweight but did not attempt to fly off with them

With pieces of suet too heavy to fly off with, Jays held them with their feet, and used their bills to twist off small pieces. Amounts ingested per visit increased as the suet aged and softened. For example, the Jays ingested an average of only $0.4 \mathrm{~g}$ per visit ( $\mathrm{n}=15$ visits) from a fresh piece of hard suet on 19 August, but as the suet softened over the next 8 days, average amount ingested increased to $0.875 \mathrm{~g}$ per visit on 24 August ( $\mathrm{n}=8$ visits), $1.45 \mathrm{~g}$ per visit on 25 August ( $\mathrm{n}=11$ visits), and $1.5 \mathrm{~g}$ on 27 August ( $\mathrm{n}=6$ visits). Each Jay weighed 1-3 g more after the initial 1-3 visits, indicating that they were retaining the initial $1-3 \mathrm{~g}$ for immediate digestion and flying off and storing what they ingested in subsequent visits.

Gray Jays were common in the study area yearround. However, I observed no scavenging or caching of suet from the onset of green-up and insect activity in early May through the end of July. When caching behavior resumed in August, they used their sticky saliva to glue caches to branches (Figure 2).

\section{Discussion}

With the exception of shrikes [Lanius spp.] (Sibley 2001), I found no report of other passerines, including other corvids, carrying food or other objects with their feet. This ability to carry food with their feet aids competition for meat scraps at carcasses. By using their feet to bring flight-loads closer to their center of lift, Gray Jays can carry heavier loads, relative to bodyweight, than can Common Ravens, which do not carry food in their feet. For example, if ravens weigh $1200 \mathrm{~g}$, as listed by Dunning (1984), an adult raven that carried a $237-\mathrm{g}$ piece of meat to a tree carried only 20 percent of its

TABLE 1. Flight-loads carried by Gray Jays in their bills or feet in northeastern Minnesota, 16 August to 21 September 1984.

\begin{tabular}{|c|c|c|c|c|}
\hline $\begin{array}{l}\text { Bird } \\
\text { weight } \\
\text { (grams) }\end{array}$ & $\begin{array}{c}\text { Load } \\
\text { weight } \\
\text { (grams) }\end{array}$ & $\begin{array}{l}\text { Percent of } \\
\text { bodyweight }\end{array}$ & $\begin{array}{l}\text { Means of } \\
\text { carrying }\end{array}$ & Comments \\
\hline $60-80^{1}$ & 11 & $14-18 \%$ & Bill & Flew easily. \\
\hline 80 & 14 & $18 \%$ & Bill & Flew easily. \\
\hline $60-80^{1}$ & 14 & $18-23 \%$ & Bill & Flew easily carrying a Deer Mouse (Peromyscus maniculatus). \\
\hline 80 & 26 & $33 \%$ & Bill & Jay rose $5 \mathrm{~m}$ at 45 degrees. \\
\hline 80 & 26 & $33 \%$ & Bill & Level flight but dropped food upon entering dense foliage. \\
\hline 60 & 25 & $42 \%$ & Feet & \\
\hline $60-80^{1}$ & 9 & $36-48 \%$ & Feet & Ascended 60 degrees to fly over a 3-meter obstacle. \\
\hline $60-80^{1}$ & 38 & $48-63 \%$ & Feet & Rose $3 \mathrm{~m}$ over a distance of $30 \mathrm{~m}$. \\
\hline 68 & 36 & $53 \%$ & Feet & Flew easily. \\
\hline 80 & 42 & $53 \%$ & Feet & Flew easily. \\
\hline 80 & 43 & $54 \%$ & Feet & Level flight and glide. \\
\hline 80 & 45 & $57 \%$ & - & Lifted food with bill but did not attempt to fly with it. \\
\hline 80 & 46 & $58 \%$ & Feet & $\begin{array}{l}\text { Dropped food 1-2 m after takeoff in first } 2 \text { attempts. Third attempt } \\
\text { successful. }\end{array}$ \\
\hline 68 & 40 & $59 \%$ & - & Lifted food with bill but did not attempt to fly with it. \\
\hline 68 & 41 & $60 \%$ & - & Lifted food with bill but did not attempt to fly with it. \\
\hline 80 & 49 & $61 \%$ & - & $\begin{array}{l}\text { Dropped food }<1 \mathrm{~m} \text { after takeoff during transfer from bill to feet } \\
\text { and abandoned it. }\end{array}$ \\
\hline 68 & 43 & $63 \%^{2}$ & Feet & Level flight low to ground. \\
\hline 68 & 43 & $63 \%$ & - & $\begin{array}{l}\text { Dropped food }<2 \mathrm{~m} \text { after takeoff during transfer from bill to feet } \\
\text { and abandoned it. }\end{array}$ \\
\hline 80 & 51 & $64 \%$ & - & $\begin{array}{l}\text { Dropped food } 1.5 \mathrm{~m} \text { after takeoff during transfer from bill to feet } \\
\text { and abandoned it. }\end{array}$ \\
\hline
\end{tabular}

${ }^{1}$ Did not determine which of the three jays took the food, so the weight range of the three was used to calculate percentage of body weight.

${ }^{2}$ This Jay ingested $2 \mathrm{~g}$ of suet in an earlier visit to the scale and still weighed $2 \mathrm{~g}$ heavier when carrying the $43 \mathrm{~g}$, making the total load $45 \mathrm{~g}$ of suet-over $66 \%$ of body weight. 


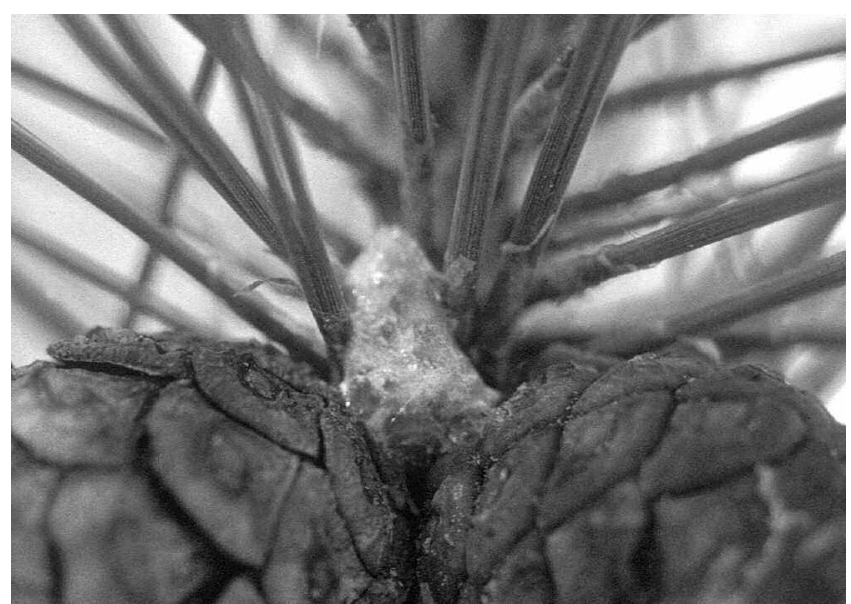

FIGURE 2. A sunflower seed cached on the tip of a Red Pine (Pinus resinosa) branch near Ely, Minnesota, in late September. Gray Jays use sticky saliva to encase food and glue it where it will remain above snow cover. It is unknown whether this encasement also preserves freshness, protects against mold and bacteria, and/or deters insects and other cache-robbers by reducing odors, making caches distasteful, or disguising them as inedible items. Photo by Lynn Rogers.

bodyweight, and an adult raven that dropped a 624-g piece of meat 1-2 meters after leaping into flight was unable to carry 52 percent of bodyweight (unpublished data). By comparison, Gray Jays fly buoyantly carrying that percentage of bodyweight in their feet (Table 1). Further, a 79.5-g male carried a 72.9-g piece of bread (92 percent of bodyweight) 20 meters in its feet before dropping it in Algonquin Provincial Park, Ontario (Strickland and Ouellet 1993).

Gray Jays opportunistically scavenge ungulate carcasses that have been opened by carnivores, ravens, eagles, and other scavengers strong enough to penetrate tough skin. Gray Jays' propensity to approach larger animals, including people, may not indicate unwariness but rather a superior willingness and ability to assess risks and food benefits. In the boreal forest in winter, risk of starvation is greater and risk of predation is lower than in relatively food-rich ecoregions farther south. For example, compared with the eastern deciduous forest, the boreal forest has longer winters, lower primary productivity, lower animal biomass (especially in winter when most birds have migrated), and lower diversity and abundance of predators (Odum 1971). Thus, selective pressures in the boreal forest, especially in winter, may favor more intensive assessment of potential food sources rather than the more cautious behavior typical of migratory birds of the boreal forest and of residents of ecoregions with more food and less extreme winters. Gray Jays' ability to carry heavy flightloads in their feet helps minimize exposure to predators and competitors at carcasses.
Gray Jays' habit of using sticky saliva to encase their food caches and glue them to branches (Figure 2) enables them to place caches where they will remain above snow cover (Dow 1965). In northeastern Minnesota, caching begins in August, leaving 3-4 months for spoilage and cache-robbing before winter. Temperatures in Ely, Minnesota, average $18^{\circ} \mathrm{C}$ in August, $13^{\circ} \mathrm{C}$ in September, $6^{\circ} \mathrm{C}$ in October, and $-4^{\circ} \mathrm{C}$ in November. Further study is needed to determine whether encasing caches in saliva preserves freshness, protects against mold and bacteria, and/or deters insects and other cache-robbers by reducing odors, making caches distasteful, or disguising them as inedible items.

The winter diet is not entirely cached food and carrion (Strickland and Ouellet 1993). On 26 January 2002, a Gray Jay ingested fruticose lichens from the trunk of a Paper Birch tree (Betula papyrifera). I found no previous report of feeding on lichens, although eating or caching fungi has been reported (Sutherland and Crawford 1979, Strickland and Ouellet 1993).

\section{Acknowledgments}

I thank A. J. Erskine, D. Strickland, and an anonymous reviewer for helpful comments.

\section{Literature Cited}

Bent, A. C. 1946. Life histories of North American Jays, crows, and titmice. Smithsonian Institution United States National Museum Bulletin 191. United States Government Printing Office. [Reprinted by Dover Publications, Inc. 1988. 495 pages, 68 plates]. 
Bock, W. J. 1961. Salivary glands in the Gray Jays (Perisoreus). Auk 78: 355-365.

Brewster, W. 1937. The birds of the Lake Umbagog Region of Maine. Bulletin of the Museum of Comparative Zoology 66: 403-521.

Dow, D. D. 1965 . The role of saliva in food storage by the Gray Jay. Auk 82: 139-154.

Dunning, J. B. 1984. Body weights of 686 species of North American birds. Monograph 1, Western Bird Banding Association. Eldon Publishing. P.O. Box 446, Cave Creek, Arizona 85331.38 pages.

Gill, D. 1974. The Gray Jay as a predator of small mammals. Canadian Field-Naturalist 88: 370-371.

Odum, Eugene T. 1971. Fundamentals of ecology, $3^{\text {rd }}$ edition. W. B. Saunders Company. Philadelphia. 574 pages.
Sibley, David Allen. 2001. The Sibley guide to bird life and behavior. Chanticleer Press, Inc., New York, and Toronto. 608 pages.

Stirling, D. 1968. Notes on food and feeding habits of some wintering birds. Canadian Field-Naturalist 82: 14-17.

Strickland, D., and H. Ouellet. 1993. Gray Jay (Perisoreus Canadensis). In The Birds of North America (40). Edited by A. Poole, P. Stettenheim, and F. Gill. Academy of Natural Sciences, Philadelphia, and American Ornithologists' Union, Washington, D.C.

Sutherland, J. B., and R. L. Crawford. 1979. Gray Jay feeding on slime mold. Murrelet 60: 28.

Received 13 September 2004

Accepted 21 February 2005 